
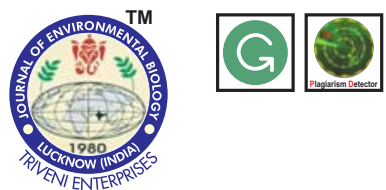

\title{
Initial growth performance of Shola species under enrichment plantation in the Nilgiris, Tamil Nadu
}

Authors Info

M. Madhu' ${ }^{1 *}$ R. Ragupathy ${ }^{2}$, H.C. Hombegowda', P. Muralidharan ${ }^{3}$ and O.P.S. Khola ${ }^{2}$

'ICAR- Indian Institute of Soil and Water Conservation, Research Centre, Sunabeda -763 002, India

${ }^{2}$ ICAR- Indian Institute of Soil and Water Conservation, Research Centre, Udhagamandalam - 643 002, India ${ }^{3}$ IICAR-CPCRI Regional station, Kayamkulam-690 533, India

${ }^{*}$ Corresponding Author Email : madhupmd@gmail.com

Key words

Afforestation,

Shola forest,

The Nilgiris,

Vegetation analysis

Publication Info

Paper received : 16.06 .2015

Revised received: 10.02 .2016

Re-revised received : 23.06 .2016

Accepted : 13.07.2016
ISSN: 0254-8704 (Print) ISSN: 2394-0379 (Online) CODEN: JEBIDP
JEB Journal of

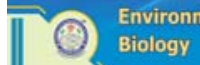

iology

ental

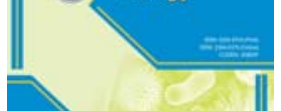




\section{Introduction}

Forests play an important role in sustaining the environment. Shola forests are unique tropical wet evergreen montane forests that occur at higher elevations (between 1400 to $2400 \mathrm{~m} \mathrm{amsl}$ ) of the Western Ghats. These forests are high altitude gallery forests restricted to valleys, depressions and especially, along the folds of hills and water courses in southern India. The shola forests are of high ecological significance in maintaining the water flow of catchment rivers. The shola forests hosts higher endemism within one of the global biodiversity hotspots (Robin and Nandini, 2012). In recent years, a high pressure was exerted on these forests due to the expansion for agriculture, plantation, other developmental and land management activity resulted in the destruction of these forest lands (Sekar, 2008; Kumar et al., 2014; Islam et al., 2015; Sahoo et al., 2015). It has been estimated that since 1850 half the shola forests in the Nilgiris have been destroyed and that the current area under sholas is about 4225 ha (Sukumar et al., 1995; Rawat et al., 2003). A latest survey in the Nilgiris have suggested that about $65 \%$ of the 180 shola pockets studied are facing a major threat from cattle grazing and wood cutting.

The study of hydrological implication of conversion of grasslands into Eucalyptus plantations has shown the reduction of about 16 and $27 \%$ in water yield for first and second rotations of Eucalyptus plantation (Sikka et al., 2003). On realizing the importance of the shola forest and long term vegetation study, the Tamil Nadu Forest Department and the district administration have taken many initiatives for conserving the existing shola vegetation and taken up enrichment planting in the degraded shola forest. Enrichment planting helps in fast recovery of such degraded forests over the natural regeneration, and improves species diversity and ecological condition (Erskine et al., 2006; Rey Benayas et al., 2009). But the success of enrichment plantations depends on the selection of species and its adaptations to the site conditions (Shankar Raman et al., 2009; van Breugel et al., 2011). Historically, re-generation of tree flora in shola fragments had been expressed as a matter of concern but a series of studies now indicate that shola species show adequate regeneration under natural conditions (Mohandass and Davidar, 2009). Initial attempts of artificially regenerating shoals in the degraded shola patches yielded little success due to the use of wildings planting material and lesser knowledge of the speciesspecific site requirement (Sekar, 2008). Subsequently to improve the ecological condition in the Nilgiris, forest department started enrichment planting with native shola species by nursery grown seedlings in the degraded sholas. However, availability of scientific studies and literature with regard to enrichment planting and artificial regeneration of sholas is meager. To achieve higher success and for the effective implementation of the enrichment plantation programme, a scientific evaluation of already afforested plantation is essential. With this background, the present study was carried out with an objective to evaluate the performance and suitability of afforested shola plant species at different sites in the Nilgiris district.

\section{Materials and Methods}

Study area : The study was conducted in the Niligiris which lies at the junction of Eastern and Western Ghats and the study region falls under the hot moist sub-humid to humid climate of the agroecological sub-region 19.2. The Niligiris are situated in the southern part of the Tamil Nadu and the area distributed across $0.25 \mathrm{M}$ ha, in a floristically rich mountain eco-system. This hill district is located between $10^{\circ} 38^{\prime}$ to $11^{\circ} 49^{\prime} \mathrm{N}$ latitude and $75^{\circ} 44^{\prime}$ to $77^{\circ} 87^{\prime}$ E longitude with elevation ranging from 400 to $2636 \mathrm{~m}$ amsl. The area is drained by innumerable perennial streams draining into the river Moyar and Bhavani, which further join together on the plains to from a tributary of the river Cauvery (Mohandass and Davidar, 2009).

Selection of afforested sites : The study was carried during 2006 to 2008 in 5year old shola species afforested plantations spread across the Niligiris district. In the present study, the performance of different shola species were investigated by measuring the survival rate and their growth characteristics and site suitability of species by a standard sampling technique. For the study, a representative 30 sites were selected among the total 77 afforested sites in the Niligiri forest division. From each afforested site detailed site characteristics was collected and analyzed to understand the site requirement for each species under different site conditions. To understand the general plant community's quick vegetation sampling method was adopted.

Characteristics of afforested sites : Necessary information of shola site characteristics was collected during the study period. The altitude of selected sites varied between 902 and $2323 \mathrm{~m}$ with an annual average rainfall between 1224 and $2739 \mathrm{~mm}$. About $30 \%$ of the sample sites located less than $1000 \mathrm{~m}$ altitude and $50 \%$ of the sample sites with average annual rainfall of more than $1500 \mathrm{~mm}$. The slope range of these sites varied from 5 to $33 \%$.

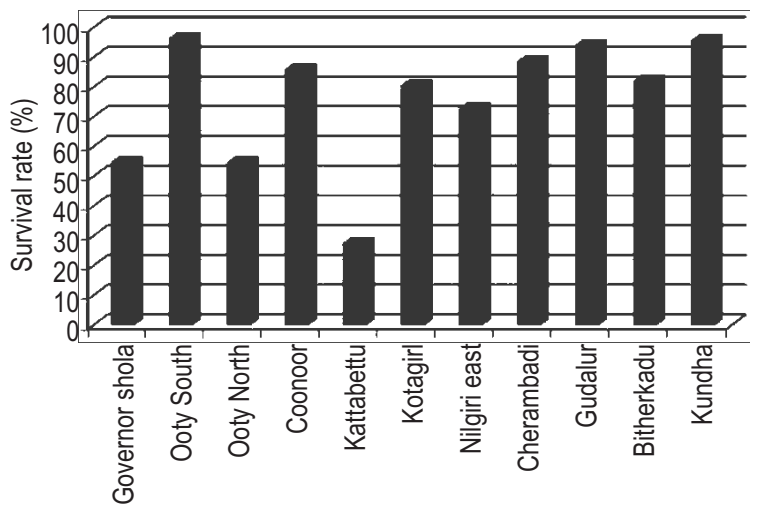

Fig. 1 : Survival rate of afforested plant species under different forest range in the Nilgiris 
Table 1 : Bio-physical parameters of dominant species at different altitude zones ( $\mathrm{Ht}$ is plant height, RCD is root collar diameter and CD is canopy diameter)

\begin{tabular}{|c|c|c|c|c|c|c|c|c|c|}
\hline \multirow[t]{2}{*}{ Dominant species } & \multicolumn{3}{|c|}{$<1000$ (m a.s.l.) } & \multicolumn{3}{|c|}{ 1000-1800(m a.s.I.) } & \multicolumn{3}{|c|}{$>1800$ (m a.s.l.) } \\
\hline & $\mathrm{Ht}(\mathrm{cm})$ & $\mathrm{RCD}(\mathrm{mm})$ & $\mathrm{CD}(\mathrm{cm})$ & $\mathrm{Ht}(\mathrm{cm})$ & $\mathrm{RCD}(\mathrm{mm})$ & $\mathrm{CD}(\mathrm{cm})$ & $\mathrm{Ht}(\mathrm{cm})$ & $\mathrm{RCD}(\mathrm{mm})$ & $\mathrm{CD}(\mathrm{cm})$ \\
\hline Syzygium cuminii & 89 & 10 & 48 & 86 & 10 & 58 & 64.9 & 10 & 33 \\
\hline Syzygium gardneri & 90 & 10 & 55 & - & - & - & 98 & 10 & 52 \\
\hline Elaeagnus oblongus & - & - & - & 53 & 10 & 25 & 47 & 10 & 37 \\
\hline Evodialunu-ankinda & - & - & - & 68 & 10 & 56 & 92 & 14 & 49 \\
\hline Ligustrum perottettii & - & - & - & 69 & 9 & 24 & 51 & 9 & 19 \\
\hline Michelia champaca & - & - & - & 169 & 30 & 94 & 202 & 50 & 103 \\
\hline Syzygium montanum & - & - & - & 78 & 10 & 33 & 50 & 13 & 24 \\
\hline
\end{tabular}

- Indicates species is absent in that elevation zone

Table 2: Quantitative vegetation parameters of afforested shola species at different aspects

\begin{tabular}{|c|c|c|c|c|c|}
\hline Aspect & Species & Relative density & Relative frequency & Relative dominance & IVI \\
\hline \multirow[t]{8}{*}{ NW } & Syzygium cuminii & 21 & 17 & 63 & 101 \\
\hline & Elaeocarpus oblongus & 18 & 11 & 13 & 42 \\
\hline & Psychotria congesta & 12 & 6 & 1 & 19 \\
\hline & Evodia lunu-ankenda & 9 & 6 & 4 & 19 \\
\hline & Syzygium gardneri & 9 & 6 & 12 & 27 \\
\hline & Berberis tinctoria & 6 & 11 & 0 & 17 \\
\hline & Litsea ligustrina & 6 & 11 & 1 & 18 \\
\hline & Melia dubia & 6 & 6 & 1 & 13 \\
\hline \multirow[t]{6}{*}{ NE } & Syzygium cuminii & 16 & 14 & 32 & 62 \\
\hline & Ligustrum perrottetii & 14 & 5 & 5 & 24 \\
\hline & Syzygium gardneri & 13 & 12 & 11 & 36 \\
\hline & Michelia champaca & 7 & 5 & 31 & 43 \\
\hline & Ilex denticulata & 6 & 2 & 1 & 9 \\
\hline & Bixaorellana & 5 & 5 & 3 & 13 \\
\hline \multirow[t]{8}{*}{ SE } & Syzygium arnottianum & 13 & 8 & 11 & 32 \\
\hline & Syzygium cuminii & 12 & 11 & 35 & 58 \\
\hline & Syzygium montanum & 12 & 11 & 7 & 30 \\
\hline & Litsea wightiana & 7 & 5 & 4 & 16 \\
\hline & Evodia lunu-ankenda & 6 & 5 & 3 & 14 \\
\hline & Ligustrum perrottetii & 6 & 5 & 3 & 14 \\
\hline & Pygeum gardineri & 6 & 3 & 2 & 11 \\
\hline & Cedrella toona & 4 & 8 & 2 & 14 \\
\hline \multirow[t]{7}{*}{ SW } & Syzygium cuminii & 15 & 7 & 31 & 53 \\
\hline & Michelia champaca & 10 & 5 & 47 & 62 \\
\hline & Ligustrum perrottetii & 8 & 5 & 3 & 16 \\
\hline & Cedrella toona & 6 & 5 & 2 & 13 \\
\hline & Syzygium arnottianum & 6 & 5 & 4 & 15 \\
\hline & Syzygium montanum & 6 & 7 & 3 & 16 \\
\hline & Daphniphyllum neilgherrense & 5 & 5 & 1 & 11 \\
\hline
\end{tabular}

NW:North-West; NE:North-East; SE:South-East; SW:South-West

The soil depth varied from $8 \mathrm{~cm}$ to more than $45 \mathrm{~cm}$ (47\% of the total sites). About $37 \%$ of the sampled sites with NE aspects followed by SE (26\%), SW (23\%) and NW (13\%).

Growth parameters studied: Growth parameters of each species were collected by following a quadrant technique $(10 \mathrm{mX}$ $10 \mathrm{~m})$. The details about the species planted at each site were also collected during the field survey through interactions with the respective forest staff in that forest range. Species-wise growth parameters viz. survival rate, plant height, root collar diameter and canopy area were collected from the each quadrant. Relative density $(R D)$, relative frequency $(R F)$, relative dominance $(R D)$ and importance value Index (IVI) were also worked out from the survey data (Mueller-Dombois and Ellenberg, 1974). 
Table 3: Suitable shola species recommended for future afforestation programme for different altitude and rainfall zones of Nilgiris

\begin{tabular}{lll}
\hline Parameter & Zone & Species \\
\hline Elevation & $900-1500$ & Syzygium cuminii, Syzygium gardneri, Michelia champaca, Syzygium montanum and Michelia nilagirica \\
(ma.s.l.) & $1500-2100$ & $\begin{array}{l}\text { Syzygium cuminii, Syzygium montanum, Syzygium arnottianum and Ligustrum perrottetii } \\
\text { Syzygium cuminii, Syzygium arnottianum, Ligustrum perrottetii and Eurya japonica }\end{array}$ \\
Rainfall (mm) & $1000-1800$ & $\begin{array}{l}\text { Syzygium cuminii, Syzygium montanum, Syzygium arnottianum, Michelia champaca, Elaeocarpus oblongus and } \\
\text { Litsealigustrina }\end{array}$ \\
& $1000-2600$ & $\begin{array}{l}\text { Syzygium cuminii, Syzygium montanum, Syzygium arnottianum, Michelia champaca, Elaeocarpus oblongus and } \\
\text { Litsealigustrina }\end{array}$ \\
& $>2600$ & Syzygium cuminii, Cinnomomum, zeylanicum and Syzygium gardneri \\
\hline
\end{tabular}

Data analysis and interpretation: The parameter wise data were compiled in tabular form and statistical parameter wise mean, range, standard deviation and co-efficient of variation was calculated and interpreted. The grouping of data was carried out for altitude, range and zone wise for better understanding and interpretation of data to analyze the species performance at different afforested sites.

\section{Results and Discussion}

Among the 52 planted species, the survival rate varied between 27 and $100 \%$ with standard deviation of 20 and CV of $27 \%$, and the average survival rate of $77.43 \%$. Out of 30 sample sites, about $23 \%$ of the sites have a survival rate of more than $90 \%$, $40 \%$ of the sites showed survival rate between 75 and $90 \%$. The average height of the saplings varied from 10 to $198 \mathrm{~cm}$, and the root collar diameter varied from 9 to $62 \mathrm{~mm}$ while the canopy area cover varied from 284 to 8720 sq.cm. The growth performance of few dominant species at different altitude is tabulated and presented in Table 1. Among all the species, Syzygium cuminii performed well in the entire three altitude group, however better growth performance was noticed at lower altitude $(<1000 \mathrm{~m})$. On the other hand Syzygium montanum was not noticed in lower altitude. Whereas, species like Elaeagnus oblongus, Evodia lunuankenda, Ligustrum perottettii and Michelia champaca performed very well above $>1000$ m elevation. Among all the planted species, maximum canopy diameter was observed in Michelia champaca. Growth parameters (height, root collar diameter and canopy cover area) wise, Michelia spp. performed better followed by Syzygium spp. Variability found in survival and growth performance in the study was due to differential in the silvicultural requirement and adaptability mechanism of species to different site conditions (Shankar Raman et al., 2009; Roman-Danobeytia et al., 2012). Similar results were reported by van Breugel et al. (2011) on the influence of site environment on the survival and growth parameters of 49 tropical plants reported from Panama forest. The forest range/shola survival percent of afforested species are presented in Fig. 1. Among the Nilgiri forest division, Governor shola, Ooty North and Kattabetta sites were registered as poor survival rate (27.3 to $54.6 \%$ ) compared to other forest range/shola in the district. Poor performance of the seedlings was due to heavy biotic interference by the grazing domestic animals and degraded site condition. However, the majority of the forest division/range recorded good to very good survival rate of afforested species in the Nilgiris district (72.7 to $96.2 \%$ ). Frequency percent of different shola species were analyzed for the all afforested sites. The frequency percent of Syzygium cuminii $(56.7 \%)$ was maximum followed by Syzygium montanum (30\%) and Syzygium gardneri (26.7\%). Under the frequency class of I, II and III, there were 48 $(88 \%), 5(10 \%)$ and $1(2 \%)$ species, during the study period. Due to wider adaptability of Syzygium spp., it was planted in almost all the sites as compared to other species.

Table 2 reveals that relative density, relative frequency, relative dominance and IVI values were highest for Syzygium cuminii and Michelia champaca as compared to other species. However, importance value index (IVI) of the dominant species varied from 9 to 101. Species like Syzygium cuminii, Elaeocarpus oblongus and Psychotria congesta recorded higher IVI under North-West aspect, where in Syzygium cuminii, Ligustrum perrottetii and Syzygium gardneri under North-East aspect, Syzygium arnottianum, Syzygium cuminii and Syzygium montanum in South-East aspect, and Syzygium cuminii, Michelia champaca and Ligustrum perrottetii in South-West aspect. About $58 \%$ of the observed shola species were found at the sites located on the SW aspect, followed by sites located in NE $(54 \%)$, SE aspect $(46 \%)$ and the lowest was found on NW (25\%)(data not shown). The shola sites facing South-Western aspect was suitable for planting number of species due to favorable site conditions available for the growth of the species. As the SW aspect shola receives more rainfall from south west monsoon which favour plants survival, there by indicating the influence of site environment on the survival and growth of the afforested plants (Shankar Raman et al., 2009; van Breugel et al., 2011). The other afforested study showed that enrichment plantations can facilitate forest succession in their understory through microclimate modification of site conditions by both physical and biologically (Park et al., 2010).

Sholas are extremely vulnerable to disturbance because the saplings do not regenerate in the open grasslands due to lack of tolerance to fire and frost (Jose et al., 1994). Initial efforts on regeneration of shola species with the planting of natural seedlings collected from the wild often met with low success rates 
(Sekar, 2002). The preliminary vegetation survey data of sholas showed that species like Michelia spp., Daphniphyllum spp., Syzygium spp., Rhododendron spp., Eurya spp., Celtis spp., Viburnum spp., Litsea spp. and Mappia spp. were predominant on the higher hills and trees like Turpinia spp., Syzygium spp., Litsea spp., Symplocos spp., Vaccinium spp., Ligustrum spp., Mappia spp. and Glochidion spp. were common in lower hills. A list of suitable species for afforestation at different altitude and rainfall range was prepared and recommendations were based on the existing species abundance and its analysis, and also based on the performance of the already afforested species at varied sites in the Nilgiris (Table 3). Site specific species recommended for afforestation in shola forests will improves the species diversity and ecological conditions of the shola and also provides favorable environmental condition for further plant succession in the forest (Parrotta etal., 1997).

From this study it can be concluded that afforestation of degraded shola forest sites is possible through enrichment plantation of nursery grown species of proposed species. The survival and growth variation among the species is mainly influenced by the site characters. Poor performance of some of the species can be due to lack of adaptability and resource availability, which clearly indicates instability of these species for artificial regeneration in degraded forest (Russo et al., 2005). The study provides basic information about the suitability of species at different altitudes, rainfall, soil and aspects for afforestation of degraded shola forest areas in the Nilgiris. The present study reveals that site condition such as elevation, aspect and site disturbance factors influence the performance of the species afforested. The recommended species from the study reveals that establishment of nursery grown plant stocks can be encouraged for large scale afforestation of shola in the Nilgiris.

\section{Acknowledgments}

We thank the Hill Area Development Project (HADP), Udhagamandalam for funding the research project and Tamil Nadu Forest Department for the support during the study period.

\section{References}

Erskine, P.D., D. Lamb and M. Bristow: Tree species diversity and ecosystem function: Can tropical multi-species plantations generate greater productivity? For. Ecol. Manage., 233, 205-210 (2006).

Islam, M.A., S.M.S. Quli, R. Rai, A. Ali and S.A. Gangoo: Forest biomass flow for fuel wood, fodder and timber security among tribal communities of Jharkhand. J. Environ. Biol., 36, 221 (2015).

Jose, S., A. Sreepathy, B.M. Kumar and V.K. Venugopal: Structural, floristic and edaphic attributes of the shola-grassland forests of Eravikulam in peninsular India. For. Ecol. Man., 65, 279-291 (1994).

Kumar, G.R.P., A.M. Hemanjal, P. Ravikumar, R.K. Somashekar and B.C. Nagaraja: Assessment of forest encroachment at Belgaum district of western Ghats of Karnataka using remote sensing and GIS. J.
Environ. Biol., 35, 259-264 (2014).

Mohandass, D. and P. Davidar: Floristic structure and diversity of a tropical montane evergreen forest (shola) of the Nilgiri Mountains, Southern India. Trop. Ecol., 50, 219-229 (2009).

Mueller-Dombois and Ellenberg: Aims and Methods of Vegetation Ecology. New York: John Wiley and Sons publications, pp. 110-120 (1974).

Park, A., M. van Breuguel, M.S. Ashton, M. Wishnie, E. Mariscal, J. Deago, Ibarra, N. Cedẽno and J.S. Hall: Local and regional environmental variation influences the growth of tropical trees in selection trials in the Republic of Panama. Forest Ecol. Manage., 260, 12-21 (2010).

Parrotta, J.A., J.W. Turnbull and N. Jones: Catalyzing native forest regeneration on degraded tropical lands. Forest Ecol. Manage., 99, 1-7 (1997).

Rawat, G.S., P.V. Karunakaran and V.K. Uniyal: Shola grasslands of Western Ghats-Conservation status and management needs. ENVIS Bulletin on Grassland Ecosystem and Agroforestry, 1, 5764 (2003).

Rey Benayas, J.M., A.C. Newton, A. Diaz and J.M. Bullock: Enhancement of biodiversity and ecosystem services by ecological restoration: A meta-analysis. Science, 325, 1121-1124 (2009).

Robin, V.V. and R. Nandini: Shola habitats on sky islands: status of research on montane forests and grasslands in southern India. Current Science, 103, 1427-1437 (2012).

Román-Dañobeytia, F.J., S.I. Levy-Tacher, J. Aronson, R.R. Rodrigues and J. Castellanos-Albores: Testing the performance of fourteen native tropical tree species in two abandoned pastures of the Lacandon rainforest region of Chiapas, Mexico. Restoration Ecology, 20, 378-386 (2012).

Russo, S.E., S.T. Davies, D.A. King and S. Tan: Soil-related performance variation and distributions of tree species in a Bornean rain forest. J. Ecol., 93, 879-889 (2005).

Sahoo, D.C., M. Madhu, P. Muralidharan and A.K. Sikka: Land management practices for resource conservation under vegetable cultivation in Nilgiris hills ecosystem. J. Environ. Biol., 36, 10391044 (2015).

Sekar, T.: Observations on survival and growth of different Shola species under a shoal afforestaion programme in Nilgiris district, Tamil Nadu. Indian Forester, 134, 451-457 (2008).

Sekar, T.: Longwood Shola Watchdog Committee-an Experiment in Shola Management in Tamil Nadu. Indian Forester, 128, 485-492 (2002).

Shankar, R., T.R., D. Mudappa and V. Kapoor: Restoring rainforest fragments: survival of mixed-native species seedlings under contrasting site conditions in the Western Ghats, India. Restoration Ecology, 17, 137-147 (2009).

Sikka, A.K., J.S. Samra, V.N. Sharda, P. Samraj and V. Lakshmanan. Low flow and high flow responses to converting natural grassland into bluegum (Eucalyptus globulus) in Nilgiris watersheds of South India. J. Hydrol., 270, 12-26 (2003).

Sukumar, R., H.S. Suresh and R. Ramesh: Climate change and its impact on tropical montane ecosystems in southern India. J. Biogeogr., 22, 533-536(1995).

van Breugel, M., J.S. Hall, D.J. Craven, T.G. Gregoire, A. Park, D.H. Dent, M.H. Wishnie, E. Mariscal, J. Deago, D. Ibarra and N. Cedeño: Early growth and survival of 49 tropical tree species across sites differing in soil fertility and rainfall in Panama. Forest Ecol. Manage, 261, 1580-1589 (2011). 